УДК 338.48-027.543 (477): 327

DOI 10.30970/vir.2019.47.0.10978

\title{
«WAR AND PEACE» OF UKRAINIAN TOURISM: THE IMPACT OF GEOPOLITICAL FACTORS ON THE TOURISM PROCESS IN UKRAINE
}

\author{
Anatoliy Parfinenko \\ V. N. Karazin Kharkiv National University, \\ 6, Svobody Sq., Khakiv, Ukraine, 61022, tel. (057) 706-06-46, \\ e-mail: parfinenko@karazin.ua
}

The article intends to highlight geopolitical aspects in the development of international tourism in Ukraine as a global phenomenon that carries out economic, social and international political action.

The paper analyzes international tourist flows in Ukraine, their dynamics and spatial structure during 2000-2017 in particular, in the context of military-political aggression on the part of Russia and intensification of Ukrainian-Russian intergovernmental relations. It has been established that the current dynamics of the international tourist flow in Ukraine is characterized by a sharp decrease in the volume of international visitors, a decrease in the rates of development of tourism activity and the reformatting of the spatial structure of the inbound and outbound tourist flow.

The question arises as to the expediency of tourism development during the military-political confrontation. The experience of holding Eurovision-2017 in Ukraine, which took place against the backdrop of the anti-terrorist operation, is highlighted. The conclusion is drawn about the constructive role of tourism as a factor of «soft power» that can influence the informing of the world about the «Ukrainian issue». In this sense, international tourist flows acted as channels of public diplomacy, reflecting the true situation in Ukraine, which is fundamentally different from the Russian mass media.

Attention is drawn to the intensification of domestic tourism in Ukraine, taking place against the backdrop of deteriorating key indicators of economic and social development. It is argued that the growth of the weight of domestic tourism was also possible due to the growth of patriotic sentiment in Ukrainian society. In a sense, the development of domestic tourism is seen as a continuation of the struggle of the Ukrainian people for their independence and territorial integrity. Consequently, the constructive role of tourism lies not only in the presentation of the country to the world community, but also in the construction of a national identity within the country. In this way domestic tourism favors further development of the Ukrainian political nation.

(C) Parfinenko Anatoliy, 2019 
Key words: international tourism; actors of geopolitical influence; Russia-Ukraine international relations; regional structure of tourism flows in Ukraine; public diplomacy.

Formulation of the problem. The growth of the openness of the international system and the associated spatial mobility of humanity is accompanied by aggravation of international and national security problems, which actualizes the need to assess the nature of current challenges for the tourism industry and hospitality. One of these challenges is the conflicts and wars that have had active and ambiguous influence on tourism over the past decades.

Tourism has played a significant role in the modernization of the socio-political life of the postcommunist countries in Central and Eastern Europe [13; 14; 15]. Ukraine is among them, where the collapse of the Soviet Union brought not only the decentralization and democratization of political systems, market transformations, but abolition of restrictions for tourist mobility. In the European region, as well as in the whole world, a new geospatial structure of tourist flows has been formed, which has influenced the formation of new world economic relations, the modernization of socio-economic and political life.

Socio-political and market transformations in post-Soviet Ukraine allowed to consider the tourist space not as a factor of ideological struggle and propaganda of the Soviet way of life, but as a source of economic development. As a result, tourism has had an impact on the intensification of socio-economic processes, which led to the formation of steady flows of inbound tourism in the country and increased its tourist attractiveness as a tourist destination. Receiving approximately 25 million foreigners per year during 2006-2013, Ukraine entered the list of the top ten leading tourist destinations of the world [23], became an influential recipient of international visitors. The spatial organization of international tourism ties in Ukraine has acquired a relatively well-established structure reflecting main geopolitical influences. Fundamental changes in the structure of the inbound tourism flow occurred in 2014 and were caused by the occupation of the peninsula of the Crimea and militarypolitical aggression of Russia in the East of Ukraine. The consequences of these events, their impact on the political environment and security in the region, and the state of development of the tourist market require a comprehensive study.

Analysis of recent research and publications. Complicated relationship between tourism and politics has become the focus of scholars relatively recently. One of the first papers, which presents the understanding of tourism as a factor of politics, international-political interaction, geopolitical influence, is presented in Richter's publications [18; 19]. This issue was developed and further conceptualized in the publications by C. Michael Hall [11; 12], who was also among the first researchers to reveal different levels of interconnection between tourism and politics (from international to individual). Numerous works by $\mathrm{C}$. Michael Hall constitute an important methodological foundation for further research on the development of tourism in conditions of political instability, the dangers of terrorist attacks in tourist 
centers, studying tourism as a practice of spreading post-colonial relations, the possibilities of using tourism as a tool of geopolitical action.

The view of tourism as a provider of peace, a factor of political stability, a tool for solving territorial conflicts in different regions of the world has attracted more and more researchers' attention in recent years. The corresponding understanding of tourism is reflected in the collective monographs edited by Burns and Novelli [9], Moufakkir and Kelly [18], Butler and Suntikul [20] and others.

Complicated relationship between tourism and war in political, economic, social, cultural and other fields is reflected in the monograph «Tourism and War» [20]. Without questioning the generally accepted thesis that the basic condition for the prosperity of tourism is peace, the editorial paper already emphasizes the superficial nature of the idea that tourism and war are always in opposition, and that the beginning of the war automatically leads to a decline or termination of peace [20, p. 3]. In this sense, the article by Timoth [21] is of particular interest that reveals the way how wars of controversially different nature can affect tourism.

Some aspects of the impact of the military conflict in Ukraine on the development of ukrainian tourism market were reflected in the works of Berryman [8], Doan and Kiptenko [10], Ivanov [16], Parfinenko [6]. In this case, it's worth considering the publication of Doan and Kiptenko [10], presented in the monograph «Tourism and geopolitics: issues and concepts from Central and Eastern Europe» (edited by Derek Hall), which highlights the impact of international and political events and economic situation in Ukraine on the main trends of tourism development since the country became independent, that is, since 1991 .

Selection of previously unsettled parts of the general problem that the article focuses on. The military-political conflict in Ukraine is mainly considered in the context of the loss of recreational potential and the volume of inbound tourism flow. Accordingly, the assessment of the influence of the geopolitical situation on the spatial structure of tourist flows remains an actual scientific problem. As well as the influence of the mentioned events on politicization of tourism itself, its transformation into a factor of foreign policy.

Formulating the purpose of the article (statement of the task). The purpose of the proposed publication is to study the influence of the geopolitical conflict in Ukraine on the dynamics and spatial structure of tourist flows in the country, the disclosure of international political action of tourism in the conditions of war and peace.

Materials and methods. The methodological basis for the study of the influence of geopolitical factors on the tourism process in Ukraine, the study of the foreign policy potential of tourism in conflict situations is represented by the theories of neoliberalism (Keohane R. \& Nye J.), the network society (Castells M.), public diplomacy and «soft force» (Guillion E., Nye J.).

The paradigm of neo-liberalism implies the full dissemination of the ideas of a free market for all areas of public life that brings it closer to globalization. Outwardly 'economic', it states fundamental (geo) political and moral implications and impacts [13, p. 4]. In the field of international relations, the theory of neo-liberalism 
implies recognizing the active role of communities of different countries, individuals and organizations as non-governmental actors of transnational cooperation. Travel and tourism are considered to be one of the forms of such interaction [17, p. 332]. Against the background of the global and inclusive nature of tourist practices, this thesis has been disseminated in the special tourism literature, where tourism is considered as a sphere of world politics [20, p. 1], «powerful mix of cultural, economic and political phenomena» [9, p. 1]. Considering tourism as a factor of geopolitics, Hall D. notes that tourism is deeply rooted in politics at all its levels. Hall D. emphasizes that tourism contributes significantly to global ordering and embraces both the symbolism and reality of 'neoliberal hegemony' [13, p. 3].

The global nature of tourist flows and their spatial organization provide grounds for arguing that tourism has a major impact on the creation of international social networks. In this sense, the theory of a network society (Castells M.) is a significant epistemological potential for understanding the nature of the influence of tourist flows on various dimensions of social existence. It implies that tourism directly affects the formation of a single world «space of flows» is an integral part of it, creating a worldwide network of tourist flows. Accordingly, the spatial structure of tourist flows analyzed in the proposed publication reflects the geopolitical tendencies of international development. The streams, notes Castells, are not just one of the elements of a social organization, they are expressions of processes that dominate our economic, political and social life [4]. In this sense, tourism is a peculiar «prism» through which general and regional peculiarities of international relations can be considered.

The work is based on official statistics that reflects the dynamics of the development of international tourist flows in Ukraine and in the world. Authors have used basic legal documents, which represent the priority directions of the tourist policy of Ukraine at the present stage. Publications of news agencies and periodicals that characterize the transformation of the tourism process in Ukraine are also widely used in the work. For understanding the transformation of the spatial structure of tourism in Ukraine, the authors used a chorological approach. Accordingly, methods of analysis of statistical data, analytical, comparative methods (tabular, graphical) are used.

The work consists of several parts. The introduction describes the main publications on the topic of work, the goals and objectives of the study are defined. The second part examines the impact of the geopolitical conflict in Ukraine on the dynamics and spatial structure of tourist flows in the country. The third part examines the transformation of the role and functions of tourism in Ukraine during the militarypolitical aggression of Russia. Conclusions and perspectives of further research are presented at the end of the publication.

Research results. Ukrainian tourism during the conflict: the space of flows or geopolitical influences? The collapse of the socialist economic system, which took place in the late 1980s and early 1990s, put forward on the agenda the question of the competitiveness of Ukrainian tourist product in the European market. To transform tourism into a factor of economic growth, Ukraine objectively had significant resource 
and infrastructure preconditions. At the same time, similar to Ukraine's resource potential and peculiarities of the country's development, such countries as Bulgaria, Poland, Romania, Slovakia, Slovenia, Hungary, Croatia, and the Czech Republic, appeared to be in a more favorable position, since socialism was not rooted deeply here, to a certain extent market relations were preserved. Ukraine did not have such experience, as a result, in the first post-Soviet decade the country had a shortfall of tourism balance. Million arriving foreigners against 10 million departing ones did not correspond to the tourist potential of the country.

The tourist policy of the last 25 years has been characterized by inconsistency, constant transformations of the central body of management in the field of tourism, lack of effective programs for supporting the industry, etc. Yet, socio-political and market transformations, as well as favorable geographical location, enabled to form stable streams of international visits and transformed the country into a significant tourist destination. During 2005-2013, Ukraine had a positive balance of tourist arrivals (Fig. 1).

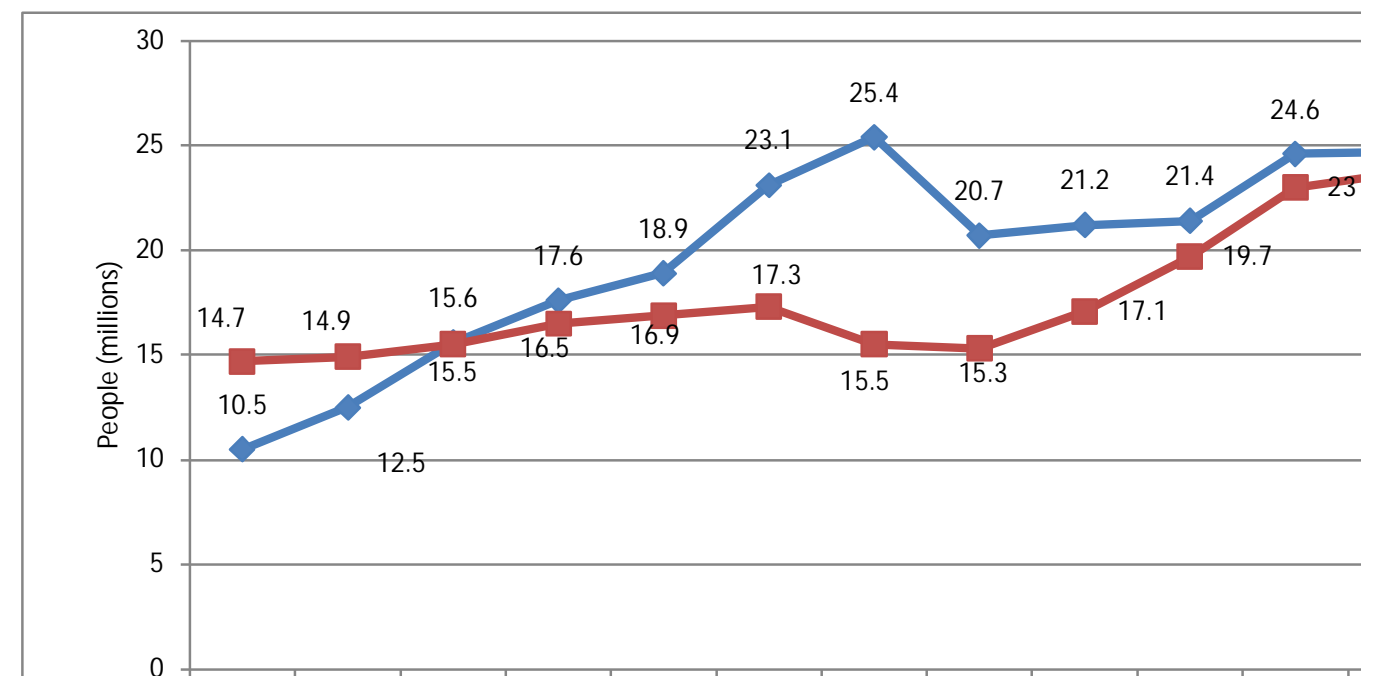

Fig. 1. Comparative dynamics of tourist arrivals and departures in Ukraine, 20022017

(Source: Committee for Statistics of Ukraine (2002-2018))

During 2000-2013 the number of tourist arrivals in Ukraine was steadily rising and almost quadrupled. So, if in 2000, 6431 million foreign tourists arrived in Ukraine, then in 2013 - 24671 million people (Fig. 1, Table 1). Over the same period, the average annual growth rate was quite stable and constituted 2,235 million people, relative rates $-13,1 \%$. The highest growth rates were recorded in $2001(42,7 \%)$, $2004(24,9 \%)$ and $2007(22,1 \%)$. Some slowdown in growth rates during 2005-2006 $(12,8 \%)$ is associated with internal organizational, economic and political factors. Indexes of inbound tourism in 2008, when more than 25,4 million people visited the country (Fig. 1, Fig. 2), became the record for Ukraine during all years of independence. An increase of $13 \%$ is observed in 2012, due to the hosting the final 
part of the European Football Championship Euro-2012. However, in 2013, despite the expectations of a large number of tourists, growth was only $0,3 \%$.

Table 1

Dynamics of absolute and relative growth of international tourist arrivals in Ukraine, 2000-2017

(Source: own calculations based on Committee for Statistics of Ukraine (20002018))

\begin{tabular}{|c|c|c|c|}
\hline Year & $\begin{array}{c}\text { Number of foreign } \\
\text { tourists } \\
\text { (in thousands) }\end{array}$ & $\begin{array}{c}\text { Absolute growth } \\
\text { (in thousands) }\end{array}$ & Relative growth, \% \\
\hline 2000 & 6430,9 & & \\
\hline 2001 & 9174,3 & 2743,2 & 42,7 \\
\hline 2002 & 10516,7 & 1342,5 & 14,6 \\
\hline 2003 & 12513,9 & 1997,2 & 19,0 \\
\hline 2004 & 15629,2 & 3115,3 & 12,8 \\
\hline 2005 & 17630,8 & 1001,6 & 7,2 \\
\hline 2006 & 18900,3 & 1269,5 & 22,1 \\
\hline 2007 & 23073,0 & 4172,7 & 10,3 \\
\hline 2008 & 25449 & 2376 & 22,3 \\
\hline 2009 & 20798 & 4651 & 2,3 \\
\hline 2010 & 21200 & 498 & 0,9 \\
\hline 2011 & 21400 & 200 & 13,0 \\
\hline 2012 & 24600 & 3200 & 0,3 \\
\hline 2013 & 24671 & 71 & 48,5 \\
\hline 2014 & 12711 & 11960 & 2,22 \\
\hline 2015 & 12428,3 & 282,7 & 6,28 \\
\hline 2016 & 13333,1 & 904,8 & \\
\hline 2017 & 14229,6 & 896,5 & \\
\hline
\end{tabular}

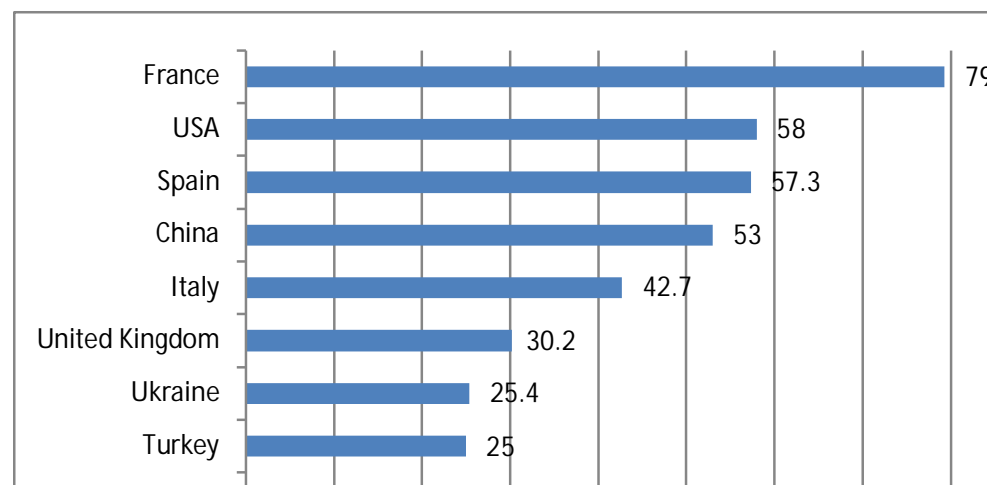

Fig. 2. Ukraine in TOP-10 tourist destinations of the world by the number of international tourist arrivals, 2008

(Source: Tourism Highlights (2008)) 
Substantial changes took place in 2014. As a result of the annexation of the Autonomous Republic of Crimea and the military aggression of the Russian Federation in the East of Ukraine, the number of foreign citizens visiting Ukraine decreased by 11960 million people (-48,5\%) and constituted 12711 million people (Fig. 1, Table 1).

The geographic structure of international tourist arrivals in Ukraine during the period of 2000-2013 evolved in an evolutionary way, however, in 2014, this process also acquired relief-rendered features. Traditionally, the largest share of foreigners coming to Ukraine was consistently made up of Russian citizens, but its volume has been steadily declining. While in 2002, Russian tourists made up 49,2 \% of tourist arrivals, then in 2013 this figure was only $41,6 \%$ (Fig. 3). In this case, the absolute value of the number of tourists coming from Russia was increasing. Compared to 2003, in 2013 their number increased by 1,8 times.

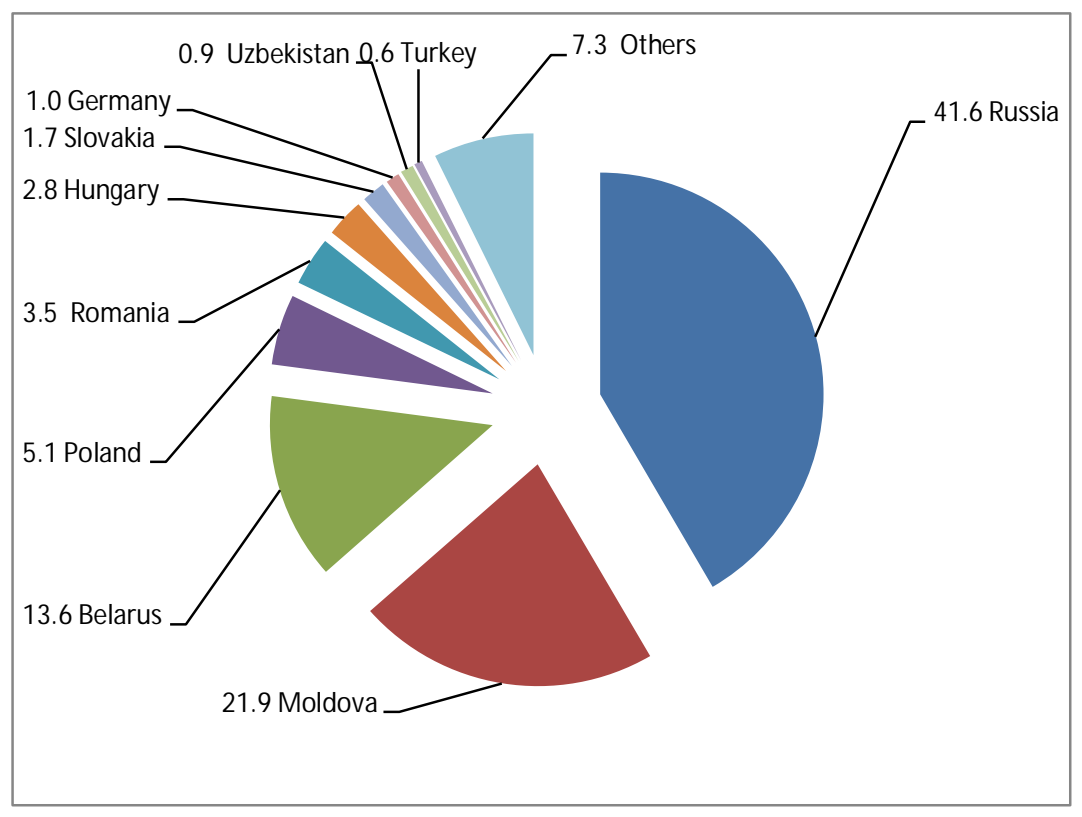

Fig. 3. Geographic structure of tourist arrivals in Ukraine, \%, 2013

(Source: own calculations based on Committee for Statistics of Ukraine (2014))

The military-political aggression of Russia has affected a significant reduction (77\% compared with 2013) in the number of foreign visitors from this country. In absolute rate this figure is 2363 million people (Table 1), which is $18,6 \%$ in the overall structure of the tourist arrivals (Figure 4). 


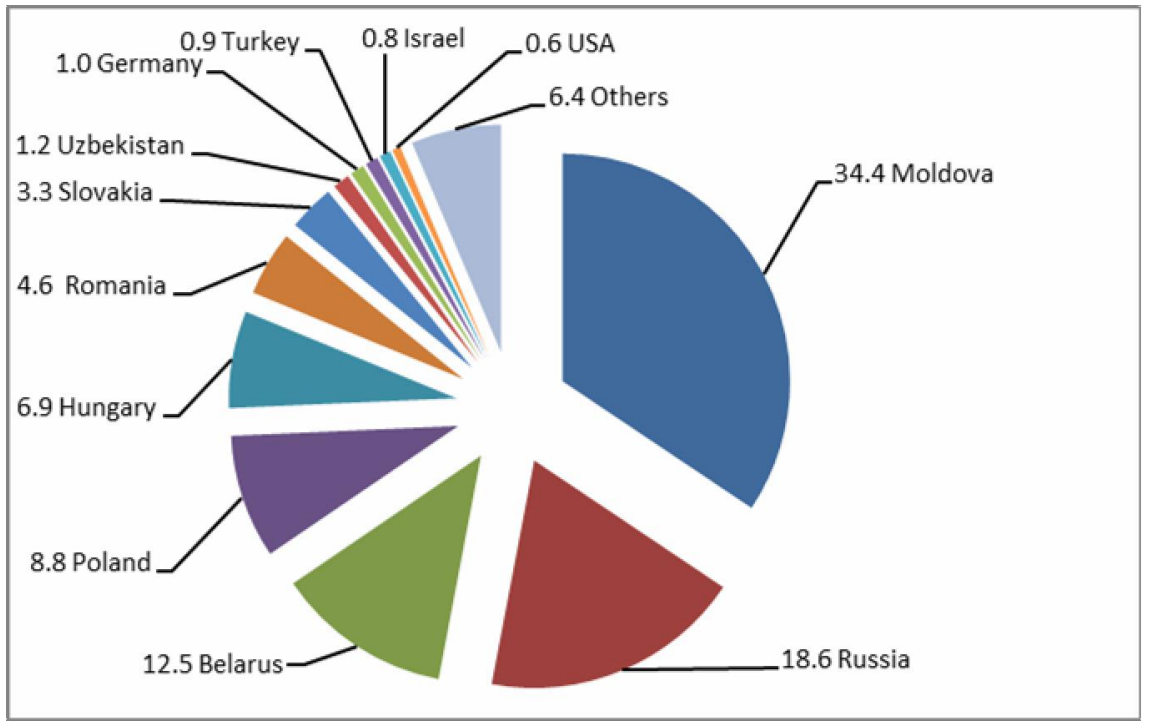

Fig. 4. Geographic structure of tourist arrivals in Ukraine, \%, 2014 (Source: own calculations based on Committee for Statistics of Ukraine (2015))

Following positions on the volume of foreign tourist arrivals are traditionally occupied by Moldova and Belarus with shares in the total tourist flow of 21,9\% and $13,6 \%$ (2013), respectively. Although the number of visitors from these countries dropped sharply in 2014 (by 19,4\% and 52,5\% respectively), their share in the structure of the tourist flow to Ukraine remains quite substantial. Thus, the share of Moldova in 2014 was the largest and made up 34,4 \%, and the share of Belarus was $12,5 \%$ (the third place after Russia in terms of tourist flow).

The military-political conflict in the East of Ukraine, not so distinctly, but it has also affected the reduction in number of travelers from the EU countries, including neighboring countries: Romania (-33\%), Poland (-10\%) and Slovakia $(-1,9 \%)$. And only the number of foreign visitors from Hungary showed positive dynamics $(+13 \%)$. The decrease in the number of foreign visitors is observed from other EU countries: Austria (-43,8), Bulgaria $(-34,6)$, Great Britain (-45,6), Italy (-39), Spain $(-41,8)$, Germany $(-48,2)$, France $(-38,2)$, Czech Republic $(-33,3)$, and other countries.

The sharp decline of international visitors is also visible from the United States $(-39,3 \%)$ and Canada $(-41,4)[3]$.

In addition to Moldova, Russia and Belarus, the aggregate share of which in the structure of international arrivals inUkraine in 2006 was 65,5\%, a rather tangible decrease in foreign citizens arrivals is observed also from other countries of the former Soviet Union: Azerbaijan (-38,2), Armenia (-6,7), Georgia (-33), Kazakhstan (-65), Kyrgyzstan $(-47,9)$, Turkmenistan $(-25,6)$, Tajikistan $(-38,5)$, Uzbekistan $(-30,5)$. The same negative dynamics is relevant for the international visits to Ukraine from the countries of the former Soviet Union, which are now included in the EU - Latvia $(-51,6)$, Lithuania $(-64,6)$, Estonia $(-55,1)$. 
The decrease in the volume of tourist arrivals continued during 2015, and only in 2016 there was a significant increase at the level of almost a million people $(7,3 \%)$. At the same time, a share of inflow from Russia continued its unabated reduction from 41,6 in 2013 to $18,6 \%$ in 2014 and to $10,3 \%$ in 2017 [3].

It should be emphasized that the volume of tourist departures from Ukraine, as it can be seen from Fig. 1, did not undergo such profound changes $(-5,3 \%)$ as the volume of tourist arrivals. Therefore, a shortfall of tourist balance according to the results of 2014 made up 43,4 \%. In 2017, the indicator of tourist departures even increased significantly and reached its historic maximum - 26,4 million people, which is obviously due not to a purely tourist purpose, but to labor migration and visiting relatives.

The spatial structure of tourist departures from Ukraine is partly similar to the spatial structure of international tourist arrivals in Ukraine. First positions in the number of foreign trips are occupied by neighboring countries. For a long time, Russia occupied the leading position in the number of foreign visits of Ukrainians, however, during the last decade its share was gradually diminishing. Rapid changes took place in 2013-2014, due to the marked exacerbation of interstate relations. While in 2013 Russia constituted 25,9\% of tourist departures, in 2014 this figure fell to $20,8 \%$, and in 2017 it decreased to 16,5\% (Fig. 5).

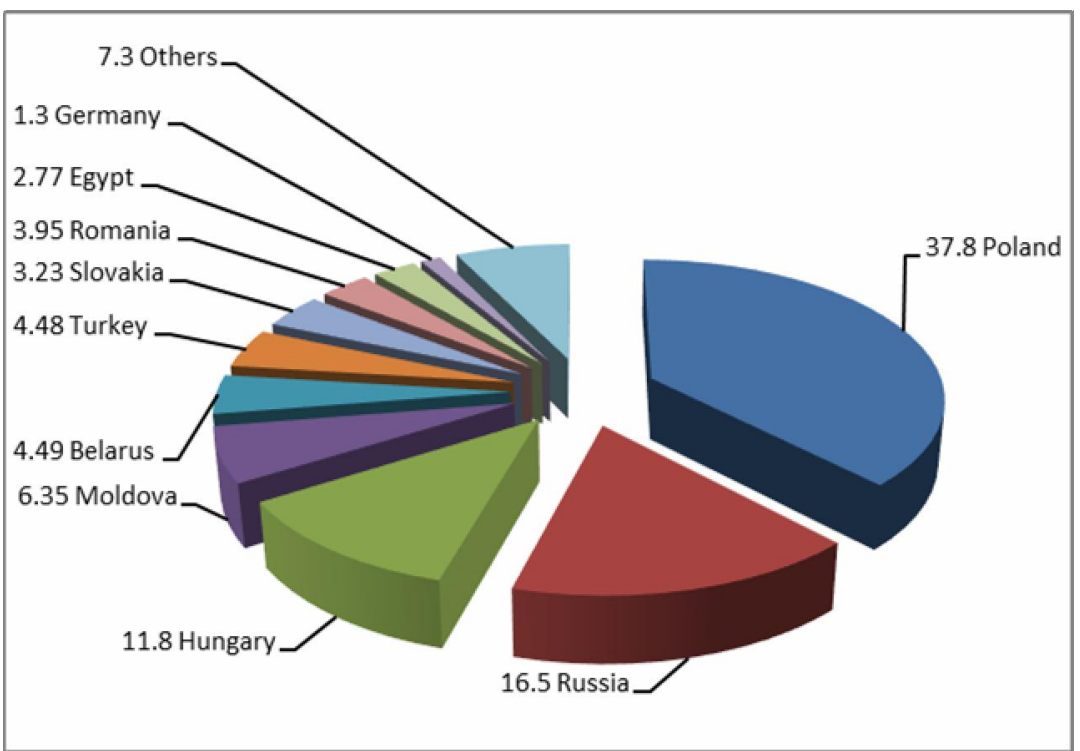

Fig. 5. Geographic structure of tourist departures from Ukraine, \%, 2017 (Source: own calculations based on Committee for Statistics of Ukraine (2018))

The analysis of the spatial structure of tourist departures from Ukraine also testifies to their significant precondition of the geopolitical events that took place during 2013-2014. This is confirmed not only by the reduction of Ukrainian citizens travelling to Russia but also by a significant increase in the number of Ukrainian 
citizens traveling to Poland and Hungary. Thus, the number of foreign visits from Ukraine to Poland in 2016 made up $41 \%$ of the total tourist departures, indicating European aspirations and geopolitical priorities of Ukraine. Consequently, one of the consequences of military-political aggression of Russia towards Ukraine was not only the reduction in the number of tourist arrivals in the country, but also an increase in the number of Ukrainians citizens travelling to the EU. It is clear that the intensification of tourist flows in this direction will promote the spread of European values and the consolidation of the European identity of Ukrainians.

Discussion. Tourism as a factor of peace and public diplomacy. In the context of this study, the question arose, how relevant the idea of the constructive role of tourism as a promoter of peace is. Recently, at the level of serious scientific articles and edited monographs, attempts are made to rethink the relationship between war and tourism, showing that the legacy of war can act not only as an obstacle, but also a resource for tourism development. In the collective monograph «Tourism and War», edited by Butler and Suntikul, in the editorial introductory article, the authors urge «to depart from the simplistic thought that war and tourism are always in opposition, that the beginning of war automatically leads to a decline or a cessation of tourism» [20, p. 3]. It is pointed out that the consequences of war for tourism can be both «negative and positive» [20, p. 3].

In the case of Ukraine, the tourist flows during the conflict, represented 1213 million foreign visitors, remained an effective tool for strengthening the foreign policy position of Ukraine. In situations of information war, direct tourist contacts played a role of a channel for disseminating information on events in Ukraine. The information war, intensified with the onset of Russian armed aggression, is aimed at providing information support to the separatist movement in eastern Ukraine, easing control of central government, and creating security and economic problems. However, Ukraine has long been a part of the European tourist area and many citizens of the EU have repeatedly visited Ukraine, including the time of the events. Being acquainted with the peculiarities of the socioeconomic and cultural life of Ukraine, traditions of Ukrainian hospitality, western neighbours of Ukraine were rather skeptical about the scenes of chaos and the full-scale war broadcast by Russian TV channels.

Among major tourist projects that helped to unite Ukraine and the EU into a single informational and communicative space, it is worth mentioning the 2005 Eurovision Song Contest, which was won by the Ukrainian singer Ruslana. Euro-2012 played a significant positive role, the final part of which was held in Ukraine and Poland. The European Football Championship was first tournament of such a kind held in the countries of Eastern Europe, and it is no accident that its slogan was «Creating history together». This project had an important political, economic, cultural and image significance for Ukraine. Poland at that time was already a member of the EU, so both countries implemented a project of a European significance. This made it possible to underline the European identity of Ukraine and to present it as a European state.

In order to disseminate reliable information on events in Ukraine, it was of a strategic importance for Ukraine to host the Eurovision Song Contest in 2017 in Kyiv, 
which, in the conditions of propaganda of the negative image of the country, was visited by more than 20 thousand foreigners [7]. Undoubtedly, this grandiose culturalentertainment event was of a great symbolic significance, since for the vast majority of foreign guests, Ukraine appeared to be not a country of a continuous conflict and war, but as a European state.

It should be noted that the European integration aspirations of the Ukrainian population are turning into a leading social request in particular since the beginning of Russian aggression. Drastic changes in the positive attitude of Ukrainians towards Euro-integration and the negative - to the alliance with Russia were established in 2014 and continue to be preserved till now. Thus, according to the data of the Institute of Sociology of the National Academy of Sciences of Ukraine, the percentage of those who favored Ukraine's accession to the alliance with Russia and Belarus has fallen from $49 \%$ in 2013 to $20 \%$ in 2017. However, the percentage of negative attitudes towards such an alliance has increased for the corresponding period from $28 \%$ to $62 \%$ in 2017 [1]. Answering a question on how you would vote in a referendum on the question of Ukraine's accession to the EU, $57 \%$ of respondents indicated that they would vote for the accession, $17 \%$ against, and the remaining $25 \%$ - either did not determine their position or did not vote [2].

The given data testify that the geopolitical turn to the West, launched by Euromaidan, became the major mainstream of the values and life sense of Ukrainian citizens. The majority of the population has no doubts about the irreversibility of the historical path of integration into the European Union. Ukraine identifies itself as a European state. This world perception is based on the geography, history, cultural traditions of the Ukrainians, is affiliated with trade and tourist links with the countries of the European Union. And tourism itself, performing the role of public diplomacy, promotes the spread, capitalization and export of Ukrainian culture. Thus, the consequence of the hybrid war against Ukraine was both the awareness of the European identity of the Ukrainians and the need to develop and use communicative potential of tourism.

Conclusions. The results of the study provide an opportunity to draw a conclusion on the significant potential of tourism as a factor of international political action. The conflict in Ukraine has affected not only the reduction of the volume of tourist arrivals, but also the intensification of the political potential of tourism itself, the use of it as an instrument of public diplomacy. In this sense international tourism has acted not only as a consumer of tourist resources, but also as an active economic and political actor, who engages in a «dialogue» with the objective-static geographical space, politicizes it, creates prerequisites both for the manifestation of socio-cultural conflict and for promoting peace.

The study of the dynamics and structure of tourist flows in Ukraine reflected a significant reduction in the volume of tourist departures that occurred as a result of the occupation of the Crimea and anti-terrorist operation in the east of the country. At the same time, these events affected radical spatial and territorial changes in the directions of tourist flows, which reflected main geopolitical priorities of Ukraine. In particular, 
the reduction of tourist exchanges with Russia was accompanied by an increase in the volume of tourist exchanges with Poland, Romania, Hungary and other EU countries.

The analysis of the peculiarities of tourism development in the context of the military-political conflict that continues in Ukraine has made it possible to fix not only the reduction of the volume of tourist arrivals, but also positive experience of using the communicative potential of tourism during Russian aggression. The conflict in Ukraine was accompanied by the revival of patriotic sentiments in society and the general support and sympathy for the country from the inhabitants of European countries. This contributed to the activation of public tourist organizations, the development of massive movement of domestic tourism, and allowed the use of international tourist flows as effective channels for the dissemination of reliable information on the situation in Ukraine.

This research has revealed several potentially interesting issues for further research, which enrich our understanding of the use of tourism as a so-called «soft power». First and foremost, will tourist flows contribute to the further integration of Ukraine into European structures? In particular, how exactly will the EU visa-free regime for Ukrainian citizens influence further modernization of socio-economic and political processes. This, undoubtedly, depends on the speedy peace settlement of the conflict in the East of Ukraine, the ability of the authorities to provide conditions for business development and an increase of social standards of living of the population. From this thesis, the following question arises: Are tourist flows capable of influencing the de-occupation of the Crimea and facilitating the reintegration of the eastern regions of Ukraine? It is obvious that the success of this case is connected with the introduction of programs supporting the development of domestic tourism, youth exchange above all. On mastering through tourist practices of a nationwide historical metanarrative, capable of constructively influencing the further formation of a modern political nation with European values.

The prospective study line proposed in this publication is to examine the role that tourism can play as a form of informal contacts, an additional tool for achieving the country's domestic political and foreign policy interests. This is particularly important in the context of the growing spatial mobility, where the intensity of tourist flows contributes to the dissemination of certain values and identities. This requires further research on measuring the impact of tourism not only on economic but also on sociopolitical and cultural processes.

\section{BIBLIOGRAPHY}

1. Більшість українців підтримують вступ до СС і НАТО: опитування [Електронний ресурс] // Європейська правда. - 2017. - 26 жовтня. - Режим доступу : http://www.eurointegration.com.ua/ news/2017/10/26/7072797/.

2. Геополітичні орієнтації жителів України: вересень 2017 [Електронний ресурс] // Київський міжнародний інститут соціології. - Режим доступу : http://www.kiis.com.ua/?lang= ukr\&cat=reports\&id=720.

3. Державна служба статистики України [Електронний ресурс]. - Режим доступу : http://www.ukrstat.gov.ua/. - 10.10.2019 p. - Загл. з екрану. 
4. Кастельс М. Информационная эпоха, экономика, общество, культура [Электронный ресурс] / Кастельс М. / Пер. с англ. под науч. ред. О. И. Шкаратана. - Москва : Высш. шк. экономики, 2000. - 606 с. - Режим доступа : http://www.gumer.info/bibliotek_Buks/Polit/ kastel/06.php.

5. Любічева О. О. Ринок туристичних послуг (геопросторові аспекти) : Монографія [Текст] / Любіцева О. О. - Київ : Альтерпрес, 2002. - 436 с.

6. Парфіненко А. Ю. Міжнародний туризм як інструмент публічної дипломатії: нові можливості для посилення зовнішньополітичного впливу України [Текст] / Парфіненко А. Ю. // Актуальні проблеми міжнародних відносин. - Вип. 127 (частина I). - 2016. - С. 27-41.

7. Стало відомо скільки туристів приїхало до Києва на Євробачення-2017 [Електронний pecypc] // УНІАН (Інформаційне агентство). - Режим доступу : https://www.unian.ua/society/ 1920321-stalo-vidomo-skilki-turistiv-prijihalo-do-kieva-na-evrobachennya-2017.html.

8. Berryman J. Crimea: geopolitics and tourism [Electronic resource] / Berryman J. // Tourism and Geopolitics: Issues and Concepts from Central and Eastern Europe / Hall D. (ed.). - Wallingford : CAB International, 2017. - P. 57-70. - Available at : https://doi.org/10.1079/9781780647616.0057.

9. Burns P., Novelli M. Tourism and Politics: Introduction [Text] / Burns P., Novelli M. // Tourism and Politics: Global Frameworks and Local Realities. - London : Elsevier, 2007. - P. 1-4.

10. Doan P., Kiptenko $V$. The Geopolitical Trial of Tourism in Modern Ukraine [Electronic resource] / Doan P., Kiptenko V. // Tourism and Geopolitics: Issues and Concepts from Central and Eastern Europe / Hall D. (ed.). - Wallingford : CAB International, 2017. - P. 71-87. - Available at : doi: 10.1079/9781780647616.0071.

11. Hall C. M. Political and Tourism: Interdependency and Implications in Understanding the Change [Text] / Hall C. M. // Tourism and Political Change Butler R., Suntikul W. (eds). - Oxford : Goodfellow, 2010. - PP. 21-32.

12. Hall C. M. Tourism and Politics [Text] / Hall C. M. - Chichester : John Wiley, 1994. - 238 p.

13. Hall D. Bringing Geopolitics to Tourism [Electronic resource] / Hall D. // Tourism and Geopolitics: Issues and Concepts from Central and Eastern Europe / Hall D. (ed.) - Wallingford : CAB International, 2017. - P. 3-14. - Available at : doi: 10,1079/+9781780647616,0003.

14. Hall D. Central and Eastern Europe: Tourism, Development and Transformation [Текст] / Hall D. // Tourism and Economic Development: European Experiences / Williams A., Shaw G. (eds.), $3^{\text {rd }}$ edn. - London : Wiley, 1998. - P. 345-373.

15. Hall D. Tourism in the Geopolitical Construction of Central and Eastern Europe (CEE) [Electronic resource] / Hall D. // Tourism and Geopolitics: Issues and Concepts from Central and Eastern Europe / Hall D. (ed.). - Wallingford : CAB International, 2017. - P. 25-37. - Available at : doi: 10.1079/9781780647616.0025.

16. Ivanov S., Gavrilina M., Webster C., Ralko V. Impacts of Political Instability on the Tourism Industry in Ukraine [Electronic resource] / Ivanov S., Gavrilina M., Webster C., Ralko V. // Journal of Policy Research in Tourism, Leisure and Events. - 2017. - No 9(1). - P. 100-127. - Available at : https://doi.org/10.1080/19407963.2016.1209677

17. Keohane R., Nye J. Transnational Relations and World Politics: An Introduction [Text] / Keohane R., Nye J. // International Organization. - 1971. - Vol. 25, No. 3. Transnational Relations and World Politics. - P. 329-349.

18. Moufakkir O., Kelly I. Tourism, progress and peace. - Wallingford : CABI, 2010.

19. Richter L. K. Tourism Politics and Political Science: A Case of not so Benign Neglect [Electronic resource] / Richter L. K. // Annals of Tourism Research. - 1983. - No 10(3). - P. 313-335. Available at : https://doi.org/10.1016/0160-7383(83)90060-9.

20. Butler R., Suntikul W. Tourism and war: An ill wind? [Text] / Butler R., Suntikul W. // Tourism and Wor / Butler R., Suntikul W. (Eds.). London : Routledge, 2013. - P. 1-11.

21. Timoth $D$. Tourism, War, and Political Instability: Territorial and Religious Perspectives [Text] / Timoth D. // Tourism and war / Butler R., Suntikul W. (Eds.). - London : Routledge, 2013. - P. 12-25.

22. Tourism and Transition: Governance, Transformation and Development [Text] / Hall D. (ed.). Wallingford : CAB International, 2004. $-272 \mathrm{p}$.

23. Tourism Highlights, 2000-2017 Edition [Electronic resource] / World Tourism Organization. Available at : http://mkt.unwto.org/publication/unwto-tourism-highlights. 


\title{
«ВІЙНА І МИР» УКРАЇНСЬКОГО ТУРИЗМУ: ВПЛИВ ГЕОПОЛІТИЧНИХ ЧИННИКІВ НА ТУРИСТИЧНИЙ ПРОЦЕС В УКРАЇНІ
}

\author{
Анатолій Парфіненко \\ Харківський наиіональний університет імені В. Н. Каразіна, \\ пл. Свободи, 6, м. Харків, Україна, 61022, тел. (057) 706-06-46, \\ e-mail: parfinenko@karazin.ua
}

Висвітлено геополітичні аспекти розвитку міжнародного туризму в Україні як глобального явища, що здійснює економічну, соціальну та міжнародно-політичну дію. Туристичні потоки розглядаються як глобальний простір соціальних мереж і відповідних економічних й геополітичних впливів. Стверджується, що просторова структура туристичних прибуттів відображає і впливає на тенденції міжнародної взаємодії.

Охарактеризовано роль та місце України на міжнародному туристичному ринку 3 урахуванням російської окупації Автономної республіки Крим. 3'ясовано, що протягом останніх десяти років Україна перетворилася на привабливу туристичну дестинацію, яка за кількістю міжнародних туристичних прибуттів (близько 25 млн) увійшла до десятки найвідвідуваніших країн світу.

Здійснено аналіз міжнародних туристичних потоків в Україні, зокрема їх динаміку та просторову структуру протягом 2000-2017 pр. в контексті військово-політичної агресії з боку Росії та загострення українсько-російських міждержавних відносин. Встановлено, що сучасна динаміка міжнародного туристичного потоку в Україні характеризується різким зменшенням обсягів міжнародних відвідувачів, зниженням темпів розвитку туристичної діяльності та переформатуванням просторової структури в'їзного та виїзного туристичного потоку.

Розглянуто питання щодо доцільності розвитку туризму під час військово-політичного протистояння. Висвітлюється досвід проведення Україною Свробачення-2017, яке відбувалося на тлі проведення антитерористичної операції. Робиться висновок про конструктивну роль туризму як чинника «публічної дипломатії», здатного впливати на інформування світу щодо «українського питання». В цьому сенсі міжнародні туристичні потоки виступили як канали публічної дипломатії, що відобразили справжню ситуацію в Україні, яка докорінно відрізняється від подання російськими ЗМІ.

Робиться висновок, що міжнародний туризм $є$ не тільки споживачем туристичних ресурсів, а й активним економічним та політичним актором, який вступає у «діалог» 3 об'єктивно-статичним географічним простором, політизує його, створює передумови як для прояву соціокультурної конфліктності, так і для забезпечення миру і міжкультурного діалогу.

Ключові слова: міжнародний туризм; актори геополітичного впливу; українсько-російські відносини; просторова структура туристичних потоків в Україні; публічна дипломатія. 